\title{
Respon Plantlet In Vitro dan Induksi Ketahanan Bibit Phalaenopsis amabilis terhadap Dickeya dadantii Menggunakan Asam Salisilat
}

\section{Response of In Vitro Plantlets and Induced Resistance of Phalaenopsis amabilis Seedling to Dickeva dadantii Using Salicylic Acid}

\author{
Uchti Nuzul Qhinanti Lubis ${ }^{1}$, Dewi Sukma ${ }^{2 *}$, dan Sudarsono ${ }^{2}$
}

${ }^{1}$ Program Studi Pemuliaan dan Bioteknologi Tanaman, Sekolah Pascasarjana, Institut Pertanian Bogor

${ }^{2}$ Departemen Agronomi dan Hortikultura, Fakultas Pertanian, Institut Pertanian Bogor

(IPB University), Jl. Meranti, Kampus IPB Darmaga, Bogor 16680, Indonesia

Diterima 22 Agustus 2020/Disetujui 27 November 2020

\begin{abstract}
Phalaenopsis is one of the most popular orchid genera because of its beautiful flower with high color variation and long flowering period. One of the problems in orchid cultivation is a bacterial soft-rot disease (SRD) caused by Dickeva dadantii. Based on the previous report, $\underline{P .}$ amabilis is one of the susceptible species to $\underline{D}$. dadantii. Induced resistance by using Salicylic Acid (SA) could be an alternative method to control SRD in Phalaenopsis. The research was conducted from November 2018 to March 2019, at Tissue Culture Laboratory, Department of Agronomy and Horticulture, IPB University. The research consisted of two experiments. The first experiment aimed to evaluate the variability responses of in vitro plantlets (seedling) from self-pollination of $\underline{\underline{P}}$ amabilis against $\underline{\underline{D}}$. dadanti by detached leaf inoculation methods and to determine their resistance levels to $\underline{D}$. dadantii. Seven out of 158 evaluated seedlings have a moderate resistance response to $\underline{D}$. dadantii, while the rest

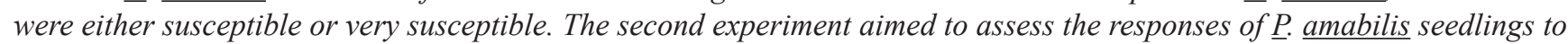
$\underline{D}$. dadantii at one day after $S A$ treatment $(0,15,30,45,60,75$, and $90 \mathrm{ppm})$ using the intact leaf inoculation method. It used a randomized block complete design (RBCD). The SA concentration at $75 \mathrm{ppm}$ was the best treatment to induce seedling resistance to soft rot pathogen $\underline{D}$. dadantii. Plants treated with $S A 75$ ppm showed the lower colony forming unit (CFU and area under the disease progress curve (AUPDC) and higher peroxidase activity than other treatments.
\end{abstract}

Keywords: disease severity, inoculation method, intact leaf, detached-leaf, soft-rot disease

\section{ABSTRAK}

Phalaenopsis merupakan salah satu anggrek yang terkenal karena keindahan bunganya dengan variasi warna yang tinggi dan periode pembungaan yang lama. Salah satu masalah dalam budidaya anggrek adalah Penyakit Busuk Lunak (PBL) yang disebabkan oleh bakteri Dickeya dadantii. Induksi resistensi dengan Asam Salisilat (AS) merupakan metode alternatif dalam mengendalikan PBL pada Phalaenopsis. Penelitian ini dilaksanakan pada bulan November 2018 sampai Maret 2019, di Laboratorium Kultur Jaringan Tanaman, Departemen Agronomi dan Hortikultura IPB. Penelitian terdiri dari dua percobaan. Percobaan 1 bertujuan untuk mengevaluasi keragaman respon planlet in vitro asal biji hasil penyerbukan sendiri P. amabilis terhadap D. dadanti dengan inokulasi pada daun terpisah dan menentukan tingkat ketahanannya. Sebanyak 7 dari 158 planlet yang diuji, memiliki respon agak tahan terhadap $\underline{D}$. dadantii, sedangkan sisanya rentan atau sangat rentan. Percobaan 2 bertujuan untuk membandingkan respon bibit $\underline{P}$. amabilis terhadap $\underline{D}$. dadantii pada 1 hari setelah perlakuan asam salisilat (AS) pada konsentrasi 0, 15, 30, 45, 60, 75, dan 90 ppm menggunakan metode inokulasi daun pada bibit yang masih menempel di tanaman. Percobaan 2 menggunakan rancangan acak kelompok lengkap teracak (RKLT). Hasil

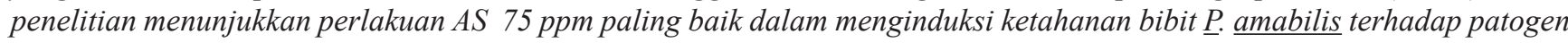
penyebab busuk lunak $\underline{D}$. dadantii. Tanaman pada perlakuan tersebut menghasilkan nilai $C F U$ dan AUPDC lebih rendah dan aktivitas peroksidase lebih tinggi dibanding perlakuan lainnya.

Kata kunci: daun terpisah, daun pada tanaman, keparahan penyakit, metode inokulasi, penyakit busuk lunak

\footnotetext{
*Penulis untuk korespondensi. e-mail: dewi_sukma@apps.ipb.ac.id
} 


\section{PENDAHULUAN}

Phalaenopsis amabilis (L.) Blume merupakan salah satu spesies anggrek yang paling terkenal dari genus Phalaenopsis dan banyak diminati oleh masyarakat karena keindahan bunganya. $P$. amabilis memiliki ciri khas bunga berukuran besar berwarna putih bersih, dan memiliki masa vase life bunga yang panjang (Alrich dan Higgins 2014; Aziz dan Sukma, 2015). Di Indonesia, P. amabilis atau disebut anggrek bulan telah ditetapkan sebagai Bunga Nasional Indonesia yang disebut dengan 'Puspa Pesona' berdasarkan Keputusan Presiden Indonesia nomor 4 Tahun 1993. Anggrek ini merupakan salah satu spesies anggrek asli Indonesia yang sering digunakan sebagai tetua dalam persilangan anggrek untuk merakit varietas anggrek bulan hibrida unggul (Semiarti et al., 2013).

Salah satu masalah penting dalam budidaya anggrek adalah serangan penyakit busuk lunak (PBL) yang disebabkan oleh bakteri Dickeya dadantii (Elina, 2016; Sukma et al., 2017; Sudarsono et al., 2018). Busuk lunak merupakan penyakit yang paling luas yang dapat merusak berbagai tanaman di seluruh dunia termasuk anggrek (Joko et al., 2013). Penyakit ini menyebar sangat cepat sehingga dalam 2-3 hari tanaman menjadi busuk dan dapat menyebabkan kerusakan hingga $80-100 \%$ terutama pada saat pembibitan. Gejala khas penyakit busuk lunak yang dimulai dari adanya luka kecil yang berair, menjadi bercak kehijauan yang basah, mengeluarkan aroma berbau busuk yang khas, dan menyebar dengan cepat ke seluruh bagian daun. Pada tanaman anggrek, penyakit ini dapat berkembang dan menyebar dengan cepat terutama pada tanaman muda atau bibit anggrek (Joko et al., 2011; Meera et al., 2016).

Pengendalian penyakit busuk lunak biasanya dilakukan dengan penyemprotan bakterisida, namun hal ini dapat mencemari lingkungan dan menurunkan kualitas tanaman karena sisa residu yang menempel pada permukaan tanaman (Firgiyanto et al., 2016). Penelitian ini dilakukan untuk mencari alternatif lain yang lebih ramah lingkungan dan efektif dalam mengendalikan penyakit busuk lunak antara lain dengan menginduksi ketahanan tanaman. Induksi ketahanan merupakan strategi untuk merangsang ketahanan sistemik tanaman terhadap serangan patogen melalui metode yang ramah lingkungan seperti penambahan senyawa penginduksi secara eksogen (Deenamo et al., 2018; Dewen et al., 2017). Salah satu senyawa yang berperan dalam menginduksi ketahanan tanaman yaitu asam salisilat (AS).

Asam salisilat (Salicylic acid) merupakan hormon yang diproduksi oleh berbagai spesies tanaman ( $\mathrm{Li}$ et al., 2019). Asam salisilat (AS) berperan dalam proses fisiologis seperti perkecambahan, termogenesis, respirasi, pertumbuhan vegetatif, senesen dan menginduksi resistensi tanaman (Rivas et al., 2011). Asam salisilat pertama kali dilaporkan sebagai senyawa yang dapat mencegah penyakit tobacco mosaic virus (TMV) pada tembakau dengan cara menginduksi Systemic Acquired Resistance (SAR) (Klessig et al., 2018). SAR adalah mekanisme ketahanan tanaman yang terbentuk di seluruh bagian tanaman setelah terjadi serangan patogen atau aplikasi senyawa kimia seperti asam salisilat (Prasannath, 2017). Ketika tanaman terinfeksi oleh patogen, kandungan AS meningkat dan sinyal transduksi mengaktifkan ekspresi gen terkait patogenesis (pathogenesis related/PR) (Li et al., 2019).

Czajkowski et al. (2015) menggunakan asam salisilat untuk mengendalikan Dickeya solani pada kultur in vitro kentang. Leiwakabessy et al. (2017) menyatakan perlakuan asam salisilat terbukti mampu untuk menginduksi ketahanan padi varietas Conde dan Ciherang untuk menekan penyebab penyakit hawar daun bakteri Xanthomonas oryzae pv. oryzae. Jendoubi et al. (2015) melaporkan bahwa pemberian asam salisilat $200 \mu \mathrm{M}$ terbukti aman dan dapat meningkatkan ketahanan tanaman tomat terhadap Fusarium oxysporum f.sp radicis lycopercisi. Sementara Noviantia et al. (2017) melaporkan bahwa konsentrasi asam salisilat 85 ppm secara in vitro efektif menekan perkembangan penyebab penyakit layu yang disebabkan oleh Fusarium oxysporum pada anggrek $P$. amabilis. Namun belum diketahui apakah planlet in vitro $P$. amabilis dapat diinduksi ketahanannya terhadap D. dadantii dengan asam salisilat.

Pengujian ketahanan tanaman terhadap patogen termasuk patogen penyebab busuk lunak dapat dilakukan dengan metode inokulasi pada daun terpisah (detached leaf inoculation method) di laboratorium atau inokulasi langsung pada daun yang masih menempel di tanaman (intact leaf inoculation method). Metode inokulasi pada daun terpisah dapat membedakan tingkat ketahanan berbagai genotipe anggrek Phalaenopsis (Elina, 2016; Sukma et al., 2017; Sudarsono et al., 2018). Metode pengujian daun terpisah tersebut sangat membantu dalam proses seleksi tanaman yang tahan. Penelitian tentang konsistensi hasil antara pengujian ketahanan anggrek Phalaenopsis terhadap $D$. dadantii pada daun terpisah dan pada daun yang masih menempel di tanaman belum banyak dilaporkan. Penelitian ini bertujuan untuk mengevaluasi respon planlet $P$. amabilis in vitro terhadap patogen busuk lunak $D$. dadantii melalui metode inokulasi daun terpisah (detached leaf inoculation method) dan respon bibit $P$. amabilis pasca perlakuan induksi ketahanan dengan AS terhadap inokulasi $D$. dadantii dengan metode inokulasi langsung pada daun yang masih menempel di tanaman (intact leaf inoculation method).

\section{BAHAN DAN METODE}

Penelitian ini terdiri dari dua percobaan yang dilaksanakan pada bulan November 2018 sampai dengan November 2019. Planlet $P$. amabilis diperoleh dari Kebun Raya Bogor. Subkultur planlet $P$. amabilis dilakukan di Laboratorium Kultur Jaringan 1, aklimatisasi dan pemeliharan bibit di Rumah Anggrek, Kebun Percobaan Leuwikopo, dan pengujian infeksi bakteri dilaksanakan di Laboratorium Pemuliaan dan Biologi Molekuler Tanaman (PMB 1), di Departemen Agronomi dan Hortikultura, Fakultas Pertanian, IPB. Analisis enzimatik dilakukan di Laboratorium Biorin, Departemen Ilmu dan Teknologi Pangan, Fakultas Teknologi Pertanian, IPB. 
Percobaan 1. Uji Respon Planlet In Vitro $\underline{\text { P. amabilis }}$ terhadap Patogen PBL D. dadantii

Percobaan ini bertujuan untuk mengevaluasi variasi respon 158 individu planlet $P$. amabilis asal benih terhadap patogen busuk lunak dan mengelompokkan planlet menurut kelas ketahanannya. Benih P. amabilis dari benih hasil penyerbukan sendiri (selfing), dikecambahkan dalam setengah konsentrasi media Murashige \& Skoog. Planlet diperoleh sekitar 10 bulan setelah penyemaian benih in vitro setelah melalui 3 kali subkultur dalam media pembesaran berupa Hyponex $2 \mathrm{~g} \mathrm{~L}^{-1}$, arang aktif $2 \mathrm{~g} \mathrm{~L}^{-1}$, ekstrak kentang $50 \mathrm{~g} \mathrm{~L}^{-1}$ ekstrak pisang $50 \mathrm{~g} \mathrm{~L}^{-1}$, vitamin MS (Murashige dan Skoog), dan gula $20 \mathrm{~g} \mathrm{~L}^{-1}$. Planlet yang diuji memiliki 3-4 daun. Bakteri $D$. dadantii yang digunakan dalam percobaan ini diisolasi dari daun tanaman anggrek yang terinfeksi PBL dari penelitian Putri (2019). Untuk inokulasi, koloni tunggal hasil subkultur dari media NA (Nutrient Agar) di kultivasi dalam $15 \mathrm{~mL}$ media LB (Lactose Broth) cair dan dikocok dengan kecepatan $100 \mathrm{rpm}$ (rotate per minute) selama 24 jam. Suspensi bakteri kemudian dipipet sebanyak $2 \mathrm{~mL}$ dan dimasukkan ke dalam microtube untuk disentrifugasi selama 6 menit dengan kecepatan 8,000 rpm. Pelet yang diperoleh dilarutkan di media LB cair, dipipet sebanyak $2 \mathrm{~mL}$ dan dimasukkan ke dalam microtube untuk disentrifugasi lagi dengan kecepatan sama selama 15 menit. Pelet yang dihasilkan dilarutkan dalam $15 \mathrm{~mL}$ media LB. Suspensi bakteri tersebut kemudian diencerkan secara berseri dengan menambahkan $1 \mathrm{~mL}$ stok suspensi ke dalam $9 \mathrm{~mL}$ akuades, sehingga diperoleh pengenceran $10^{-1}$, diteruskan hingga diperoleh pengenceran $10^{-3}$.

Metode uji ketahanan planlet terhadap $D$. dadantii menggunakan metode inokulasi daun terpisah (detached leaf inoculation method mengikuti metode yang dilaporkan Sukma et al. (2017) dan Sudarsono et al. (2018). Pengamatan respon daun planlet $P$. amabilis terhadap infeksi bakteri penyebab penyakit busuk lunak dilakukan dengan mengukur diameter gejala busuk lunak setiap 6 jam sekali selama masa inkubasi dimulai dari 12 sampai 48 jam setelah inokulasi (JSI). Perhitungan keparahan penyakit (KP) dan kelas ketahanan (KK) planlet dihitung menggunakan rumus pada penelitian Sanjaya et al. (2020).

$$
K P=\frac{\Sigma(n i \times v)}{Z \times N} \times 100 \%
$$

Keterangan :

$n i=$ jumlah daun terserang pada skor ke-1, $v=$ skor penyakit pada skala i, $\mathrm{Z}=$ nilai skor tertinggi, $\mathrm{N}=$ jumlah tanaman yang diamati. Skor gejala $(v)$ ditetapkan berdasarkan kriteria sebagai berikut: $1=$ diameter gejala $\leq 1 \mathrm{~mm}, 3=$ diameter gejala $2<\mathrm{i} \leq 4 \mathrm{~mm}, 5=$ diameter gejala $4<\mathrm{i} \leq 6 \mathrm{~mm}, 7=$ diameter gejala $6<\mathrm{i} \leq 8 \mathrm{~mm}, 9=$ diameter gejala $>8 \mathrm{~mm}$.

Kelas ketahanan (KK) planlet terhadap $D$. dadantii ditentukan berdasarkan kriteria Keparahan Penyakit (KP) sebagai berikut: tahan (T) untuk KP antara $0-20 \%$, agak tahan (AT) untuk KP antara 21-40\%, agak rentan (AR) untuk KP antara $41-60 \%$, rentan (R) untuk KP antara 61$80 \%$, sangat rentan (SR) untuk KP lebih dari $80 \%$.
Percobaan 2. Uji Konsentrasi Asam Salisilat (AS) untuk Induksi Ketahanan Bibit P. amabilis di Greenhouse terhadap Infeksi Patogen PBL $\underline{D}$. dadantii.

Bahan tanaman yang digunakan berupa bibit anggrek P. amabilis yang berumur 4 bulan setelah aklimatisasi di greenhouse dan memiliki 3 sampai 5 daun. Bibit merupakan sampel acak dari populasi bibit hasil silang sendiri (selfing) $P$. amabilis yang belum diketahui tingkat ketahanannya terhadap $D$. dadantii. Bibit tanaman tersebut dibawa ke Laboratorium, disemprot dengan AS sesuai konsentrasi perlakuan, hingga seluruh daun tanaman basah merata. Percobaan menggunakan satu faktor perlakuan yaitu konsentrasi AS dalam rancangan kelompok lengkap teracak (RKLT) dengan ulangan sebagai kelompok. Konsentrasi perlakuan AS terdiri dari $7 \operatorname{taraf}(0,15,30,45,60,75$, dan 90 ppm) dan diulang sebanyak 3 kali dengan 1 tanaman sebagai 1 ulangan. Inokulasi bakteri $D$. dadantii dilakukan satu hari setelah perlakuan AS. Persiapan bakteri dilakukan seperti percobaan 1 dan menggunakan pengenceran $10^{-2}$ untuk inokulasi. Metode inokulasi dilakukan dengan inokulasi langsung pada daun yang masih menempel di tanaman (intact leaf inoculation method). Daun yang diinokulasi adalah daun nomor 2 (dihitung dari pangkal tanaman) $P$. amabilis. Permukaan atas daun pada bagian tengah lamina (bukan tulang daun) ditusuk dengan jarum steril sebanyak satu kali, kemudian inokulum bakteri dengan pengenceran $10^{-2}$ sebanyak $10 \mu \mathrm{L}$ diteteskan di atas permukaan daun yang luka menggunakan mikropipet. Bibit anggrek kemudian diinkubasi di dalam container box dengan suhu $25-30{ }^{\circ} \mathrm{C}$.

Pengamatan respon daun bibit $P$. amabilis yang diinokulasi bakteri $D$. dadantii dilakukan dengan mengukur diameter gejala busuk lunak pada daun, selanjutnya perhitungan keparahan penyakit (KP) dan kelas ketahanan (KK) dilakukan seperti pada percobaan 1. Disamping itu, juga dihitung area di bawah kurva progres penyakit (area under the disease progress curve (AUDPC)) yang dihitung berdasarkan KP pada 18, 24, dan 30 JSI mengikuti metode Campbell \& Madden (1990) dalam Yap (2017).

$$
\text { AUDPC }=\sum_{i}^{n-1}\left(\frac{x i+(x i+1)}{2}\right)((t i+1)-t i)
$$

Keterangan:

$\mathrm{x}=$ Persentase keparahan penyakit, $\mathrm{t}=$ selang waktu pengamatan.

Analisis aktivitas peroksidase dilakukan mengikuti metode Sukma et al. (2008) dan Firgiyanto et al. (2016). Sampel yang digunakan yaitu bagian ujung daun bibit anggrek yang tidak terkena gejala busuk, dipotong dari masing-masing tanaman dan digabung sebagai sampel komposit untuk setiap konsentrasi perlakuan AS. Sampel komposit yang digunakan untuk analisis peroksidase sebanyak $1 \mathrm{~g}$. Protein total dari jaringan daun diekstrak dengan buffer fosfat. Sebanyak $100 \mu \mathrm{L}$ ekstrak protein jaringan ditambahkan ke dalam larutan $2.5 \mathrm{~mL}$ pirogalol $0.2 \mathrm{M}$, lalu ke dalam campuran tersebut ditambahkan $\mathrm{H}_{2} \mathrm{O}_{2}$ (1\%) sebanyak $250 \mu \mathrm{L}$. Nilai absorbansi larutan sesudah 
reaksi diukur dengan menggunakan spektrofotometer pada panjang gelombang $\lambda 420 \mathrm{~nm}$ setiap 30 detik dalam periode 0-150 detik, dengan menggunakan blanko campuran larutan yang sama tetapi tanpa ekstrak protein. Sebagai ganti ekstrak protein, ke dalam larutan blanko ditambahkan larutan penyangga fosfat. Aktivitas peroksidase dihitung sebagai peningkatan nilai absorbansi per satuan waktu per bobot protein $(\Delta \mathrm{A} 420 / \mathrm{menit} / \mathrm{mg}$ protein) pada kondisi analisis.

Pada percobaan 2 diamati Colony Forming Unit (CFU), untuk mengetahui jumlah koloni bakteri yang terdapat daun yang bergejala busuk lunak. CFU dihitung dengan mengambil $50 \mathrm{mg}$ bagian daun antara yang terkena gejala dan yang tidak bergejala pada 30 JSI. Bagian daun tersebut digerus hingga halus dan larutkan dengan $1 \mathrm{~mL}$ akuades steril selanjutnya diencerkan sampai tiga kali. Masing-masing pengenceran diambil sebanyak $3 \mu \mathrm{L}$ dan diteteskan di atas permukaan media Nutriet Agar (NA) dengan tiga ulangan. Koloni yang muncul dihitung setelah media diinkubasi selama 24 jam dalam suhu kamar.

Data yang diperoleh dianalisis dengan menggunakan aplikasi Microsoft Excel 2016 dan STAR (Statistical Tool for Agricultural Research). Pengaruh nyata perlakuan diuji dengan analisis sidik ragam dan jika perlakuan berpengaruh nyata diuji lanjut dengan BNJ pada $\alpha=0.05$.

\section{HASIL DAN PEMBAHASAN}

\section{Percobaan 1. Respon Planlet In Vitro $\underline{\text { P. amabilis terhadap }}$ Patogen PBL D. dadantii}

Hasil uji respon planlet $P$. amabilis setelah diinokulasi patogen $D$. dadantii dapat dilihat pada Tabel 1. Hasil pengujian menunjukkan bahwa dari 158 planlet yang diuji, $56.7 \%$ (90 planlet) anggrek menunjukkan kelas ketahanan sangat rentan (SR) diikuti oleh kelas ketahanan rentan (R) sebanyak 22.2\% (35 planlet, agak rentan (AR) sebanyak 16.5\% (26 planlet) dan agak tahan (AT) sebanyak 4.4\% (7 planlet). Planlet dengan kelas ketahanan tahan $(\mathrm{T})$ tidak ditemukan sama sekali. Hasil ini menunjukkan bahwa secara umum $P$. amabilis tidak tahan terhadap D. dadantii, sesuai dengan hasil penelitian-penelitian yang dilakukan sebelumnya yang menyatakan anggrek $P$. amabilis merupakan spesies yang rentan terhadap penyakit busuk lunak (Sukma et al., 2017; Sanjaya et al., 2020). Respon ketahanan yang berbeda dari individu planlet menunjukkan kemungkinan adanya variasi genetik pada planlet walaupun benih dihasilkan dari penyerbukan sendiri, namun dugaan tersebut perlu dibuktikan lebih lanjut melalui analisis molekuler pada planlet. Suryowinoto (1990) menyatakan dalam satu buah anggrek dapat menghasilkan biji 2-3 juta, ketidakpastian sebagai galur murni mengakibatkan tanaman yang dihasilkan mempunyai variasi genetik yang besar.

Percobaan 2. Konsentrasi Asam Salisilat (AS) untuk Induksi

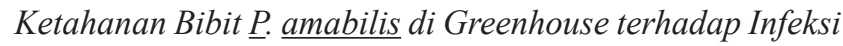
Patogen PBL $\underline{D}$. dadantii

Diameter gejala, keparahan penyakit dan kelas ketahanan bibit setelah uji konsentrasi AS dan inokulasi bakteri penyebab penyakit busuk lunak langsung pada daun yang masih menempel di batang bibit anggrek $P$. amabilis dapat dilihat pada Tabel 2. Perlakuan AS berpengaruh nyata terhadap diameter gejala busuk lunak pada pengamatan 24 JSI. Diameter gejala busuk lunakyang paling besar ditemukan pada kontrol (AS $0 \mathrm{ppm}$ ) namun tidak berbeda nyata dengan perlakuan AS 15, 30, dan 45 ppm. Diameter gejala busuk lunak pada perlakuan AS 60, 75, dan 90 ppm tidak berbeda nyata satu sama lainnya namun nyata lebih rendah dibanding kontrol dan perlakuan konsentrasi AS 30 ppm. Terdapat koefisien keragaman respon diameter gejala yang cukup besar (sekitar 20\%) dalam setiap waktu pengamatan. Secara umum terlihat kecenderungan menurunnya gejala busuk lunak dengan peningkatan konsentrasi AS. Respon luas gejala busuk lunak pada setiap konsentrasi AS pada pengamatan 24 jam setelah inokulasi dapat dilihat pada Gambar 1. Bibit pada perlakuan AS 60, 75, dan 90 ppm

Tabel 1. Diameter gejala, keparahan penyakit dan kelas ketahanan planlet in vitro $P$. amabilis terhadap patogen busuk lunak D. dadanti pada 24 JSI

\begin{tabular}{|c|c|c|c|}
\hline Nomor aksesi & $\begin{array}{l}\text { Diameter gejala } \\
\text { busuk lunak }(\mathrm{mm})\end{array}$ & $\begin{array}{l}\mathrm{KP} \\
(\%)\end{array}$ & KK \\
\hline $1,10,17,23,119,167,192$ & $3.7 \pm 1.5$ & 33 & AT \\
\hline $\begin{array}{l}6,9,11,19,20,21,120,129,130,139,152,161,162,163,164,165,166,168 \\
171,172,173,174,175,176,179,191\end{array}$ & $4.8 \pm 0.8$ & 56 & AR \\
\hline $\begin{array}{l}3,4,5,7,8,13,14,24,25,30,31,32,34,36,37,38,39,40,41,42,132,135 \\
150,151,159,160,170,177,178,182,183,187,189,190,193\end{array}$ & $6.5 \pm 0.5$ & 78 & $\mathrm{R}$ \\
\hline $\begin{array}{l}2,12,15,16,18,22,26,27,28,29,33,43,45,46,47,48,49,50,51,53,54,55, \\
56,57,58,59,60,61,62,63,64,65,67,69,70,71,72,73,75,77,78,80,81,82, \\
84,89,92,98,121,122,123,124,125,126,127,128,131,134,136,137,138, \\
140,141,142,144,145,146,147,148,149,153,154,155,156,157,158,169, \\
180,181,184,185,186,200,201,202,203,204,205,206,207\end{array}$ & $9.3 \pm 1.0$ & 100 & SR \\
\hline
\end{tabular}

Keterangan: Data merupakan rata-rata \pm standar deviasi; JSI $=$ jam setelah inokulasi; $\mathrm{KP}=$ keparahan penyakit; $\mathrm{KK}=$ kelas ketahanan; $\mathrm{AT}=$ agak tahan; $\mathrm{AR}=$ agak rentan; $\mathrm{R}=$ rentan; $\mathrm{SR}=$ sangat rentan 
Tabel 2. Pengaruh konsentrasi asam salisilat (AS) terhadap diameter gejala, keparahan penyakit busuk lunak yang disebabkan D. dadantii dan kelas ketahanan bibit $P$. amabilis terhadap D. dadantii dengan intact leaf inoculation method

\begin{tabular}{|c|c|c|c|c|c|}
\hline \multirow{2}{*}{$\begin{array}{l}\text { Konsentrasi AS } \\
(\mathrm{ppm})\end{array}$} & \multicolumn{3}{|c|}{ Diameter gejala busuk lunak (mm) } & \multirow{2}{*}{$\begin{array}{l}\mathrm{KP} \\
(\%)\end{array}$} & \multirow{2}{*}{ KK } \\
\hline & 18 JSI & $24 \mathrm{JSI}$ & $30 \mathrm{JSI}$ & & \\
\hline 0 & $7.20 \pm 3.25 \mathrm{a}$ & $9.55 \pm 0.64 a$ & $10.0 \pm 0.00 \mathrm{a}$ & 100 & $\mathrm{R}$ \\
\hline 15 & $4.43 \pm 1.40 \mathrm{ab}$ & $6.93 \pm 0.91 \mathrm{ab}$ & $9.07 \pm 0.90 \mathrm{ab}$ & 78 & $\mathrm{R}$ \\
\hline 30 & $7.20 \pm 1.49 \mathrm{a}$ & $9.17 \pm 1.19 \mathrm{a}$ & $9.80 \pm 0.35 \mathrm{a}$ & 93 & SR \\
\hline 45 & $2.57 \pm 1.00 \mathrm{ab}$ & $4.10 \pm 2.15 \mathrm{abc}$ & $9.63 \pm 0.64 \mathrm{a}$ & 48 & $\mathrm{AR}$ \\
\hline 60 & $0.73 \pm 1.27 \mathrm{~b}$ & $1.07 \pm 1.85 \mathrm{c}$ & $2.57 \pm 4.45 \mathrm{bc}$ & 11 & $\mathrm{~T}$ \\
\hline 75 & $0.93 \pm 1.62 b$ & $1.20 \pm 2.08 \mathrm{c}$ & $1.57 \pm 2.71 \mathrm{c}$ & 11 & $\mathrm{~T}$ \\
\hline 90 & $1.23 \pm 2.14 \mathrm{~b}$ & $1.90 \pm 3.29 b c$ & $2.17 \pm 3.75 b c$ & 19 & $\mathrm{~T}$ \\
\hline Koefisien keragaman & $21.62 \%$ & $19.94 \%$ & $21.64 \%$ & & \\
\hline
\end{tabular}

Keterangan: Angka yang diikuti huruf yang sama pada kolom yang sama tidak berbeda nyata pada uji beda nyata jujur (BNJ) dengan $\alpha$ $=5 \%$. JSI = Jam Setelah Inokulasi. $\mathrm{KP}=$ keparahan penyakit; $\mathrm{KK}=$ kelas ketahanan; $\mathrm{R}=$ rentan; $\mathrm{SR}=$ sangat rentan; $\mathrm{AR}=$ agak rentan; $\mathrm{T}=$ tahan

menunjukkan tingkat keparahan lebih rendah, 11\% (60 dan $75 \mathrm{ppm}$ ) dan 19\% (90 ppm) dibanding perlakuan lainnya $(>40 \%)$. Bibit pada ketiga perlakuan tersebut termasuk ke dalam kelas ketahanan tahan $(\mathrm{T})$ terhadap $D$. dadantii, namun konsentrasi terbaik adalah pada AS 75 ppm karena menghasilkan intensitas penyakit dan CFU paling rendah.

Hasil analisis aktivitas enzim peroksidase dapat dilihat pada Gambar 2. Bibit pada perlakuan AS 75 ppm menunjukkan aktivitas peroksidase paling tinggi dibanding perlakuan lainnya yaitu $0.000476 \mathrm{U}$ per menitper mg protein, sedangkan perlakuan konsentrasi AS 30 ppm memiliki nilai peroksidase paling rendah yaitu $0.000091 \mathrm{U}$ per menit per mg protein. Hasil tersebut menunjukkan ketidakstabilan respon aktivitas peroksidase terhadap konsentrasi AS yang perlu dievaluasi lebih lanjut. Aktivitas peroksidase yang tinggi diduga kuat menekan pertumbuhan bakteri pada daun dari perlakuan AS 75 ppm. Peroksidase merupakan enzim antioksidan yang aktivitasnya berkorelasi kuat dengan penekanan penyakit (Yasmin et al., 2016).

Hasil CFU pada daun bibit $P$. amabilis yang diinokulasi bakteri $D$. dadantii dengan metode intact leaf inoculation method pada pengamatan 30 JSI dapat dilihat pada Tabel 3. Rata-rata hasil CFU pada pengenceran gerusan daun terinfeksi $10^{-1}$ menghasilkan konsentrasi bakteri yang sangat tinggi sehingga tidak dapat dihitung jumlah koloninya. Sebaliknya pada konsentrasi AS 75 ppm, hanya terdapat 2 koloni bakteri pada pengenceran $10^{-1}$, menunjukkan tertekannya pertumbuhan sel bakteri pada daun tanaman. Seluruh daun pada semua perlakuan konsentrasi AS, CFU dapat dihitung pada pengenceran $10^{-2}$. CFU paling tinggi ditemukan pada perlakuan konsentrasi AS 45 ppm yaitu sebanyak 50 koloni tunggal. Nilai AUPDC pada perlakuan AS 60, 75, dan 90 ppm terlihat pada Gambar 1B. Diameter gejala yang lebih kecil akan menghasilkan nilai AUPDC yang lebih rendah. Aktivitas peroksidase yang tinggi pada perlakuan AS 75 ppm (Gambar 2) diduga merupakan salah satu yang menekan pertumbuhan bakteri pada daun yang diinokulasi sehingga CFU dari daun pada perlakuan tersebut menjadi lebih rendah dibanding perlakuan lainnya.

Hasil Percobaan 1 dan 2 mengkonfirmasi hasil penelitian sebelumnya seperti dilaporkan Sukma et al., 2017 dan Sanjaya et al. (2020), dimana P. amabilis merupakan
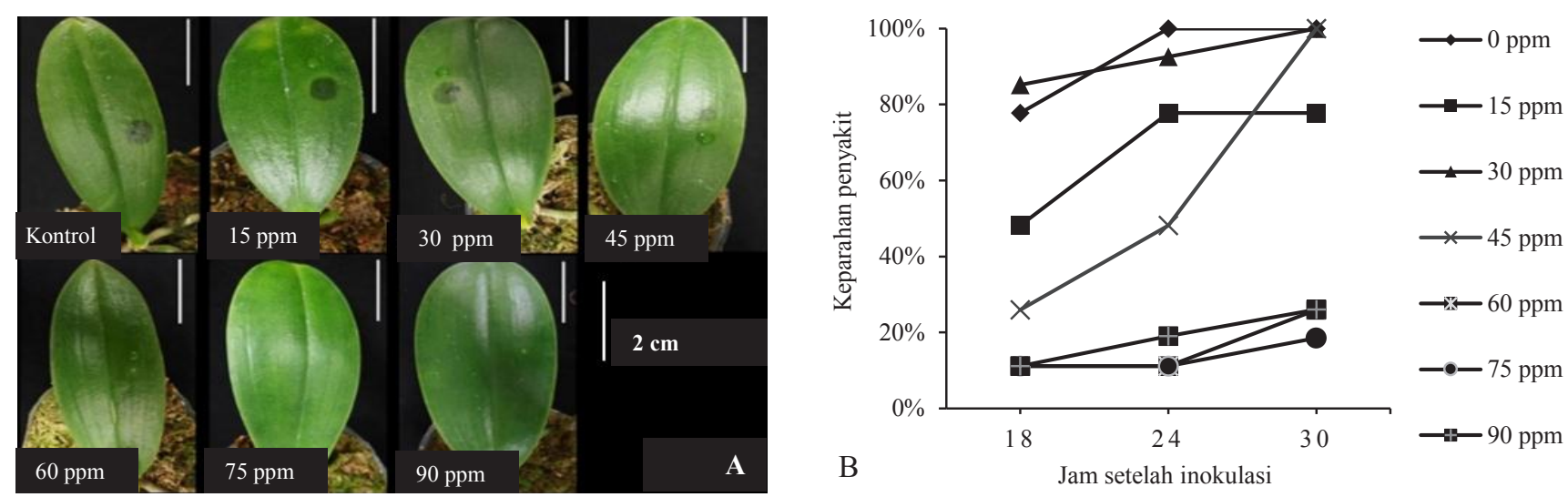

Gambar 1. (A) Gejala busuk pada daun bibit P. amabilis pada 24 jam setelah inokulasi D. dadantii pada berbagai perlakuan konsentrasi asam salisilat (AS), (B) Grafik area under disease progress curve (AUPDC) pada perlakuan konsentrasi asam salisilat (AS) 


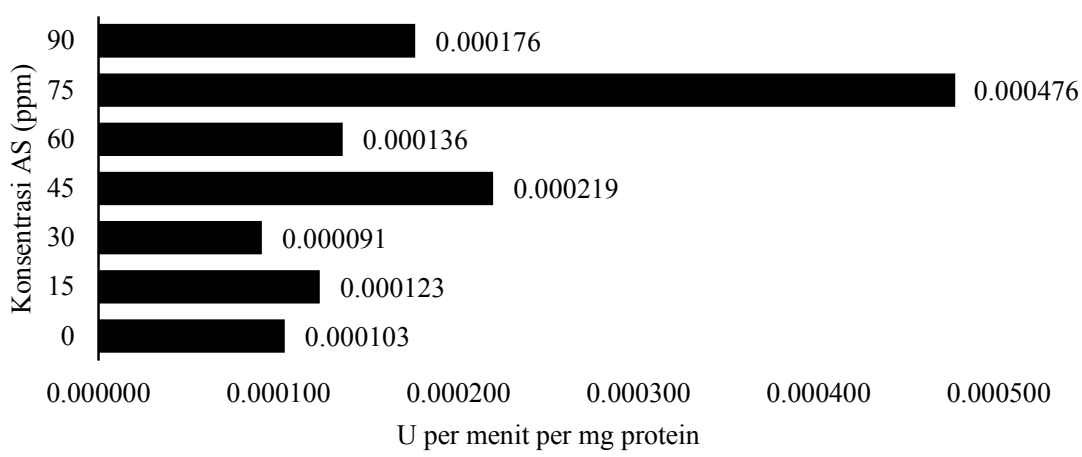

Gambar 2. Aktivitas peroksidase pada daun bibit anggrek P. amabilis yang diinokulasi D. dadantii dengan intact leaf inoculation method pada 30 jam setelah inokulasi pada perlakuan induksi ketahanan dengan asam salisilat (AS)

salah satu spesies anggrek yang rentan terhadap busuk lunak. Putri (2019) menyatakan kematian bibit anggrek $P$. amabilis yang disebabkan oleh penyakit busuk lunak sangat tinggi di greenhouse mencapai $78 \%$ setelah dua bulan fase aklimatisasi. Terdapatnya beberapa planlet yang agak tahan terhadap $D$. dadantii menunjukkan kemungkinan adanya variasi genetik antar planlet yang berkaitan dengan respon terhadap D. dadantii. Raynalta et al. (2018) dan Humaira et al. (2020) melaporkan adanya variasi antar klon planlet asal seedling in vitro $P$. amabilis dalam respon terhadap $D$. dadantii dan analisis keragaman dengan marka Pto-SNAP.

Hasil percobaan 1 menunjukkan adanya variasi ketahanan planlet $P$. amabilis terhadap $D$. dadantii yang diduga berasal dari faktor genetik tanaman. Sementara pada hasil Percobaan 2, terlihat bahwa konsentrasi 60 dan 75 ppm AS dapat menginduksi ketahanan tanaman terhadap D. dadantii. Adanya keragaman respon planlet pada Percobaan 1 menimbulkan keraguan apakah ketahanan pada perlakuan AS 60 dan 75 ppm benar-benar meningkatkan ketahanan tanaman atau karena faktor genetik tanaman, karena itu penelitian ini perlu dilanjutkan dengan mengujj AS pada bibit asal perbanyakan klonal dari genotipe rentan P. amabilis. Sanjaya et al. (2020) melaporkan bahwa AS 60 ppm tidak meningkatkan ketahanan berbagai spesies Phalaenopsis terhadap $D$. dadantii, namun ketahanan sedikit meningkat dengan perlakuan AS 720 ppm pada P. amabilis. Konsistensi AS dalam menginduksi ketahanan tanaman anggrek Phalaenopsis terhadap penyakit busuk lunak yang disebabkan $D$. dadantii masih perlu diteliti lebih lanjut.

Tabel 3. Colony forming unit (CFU) D. dadantii asal daun bibit anggrek P. amabilis pada perlakuan induksi ketahanan dengan AS dari daun yang bergejala busuk lunak pada 30 jam setelah inokulasi

\begin{tabular}{lcccc}
\hline \multirow{2}{*}{ Konsentrasi AS $(\mathrm{ppm})$} & \multicolumn{3}{c}{ Jumlah koloni bakteri } & Coloni forming unit (CFU) \\
\cline { 2 - 5 } & $10^{-1}$ & $10^{-2}$ & $10^{-3}$ & $8.8 \times 10^{6}$ \\
15 & $\sim$ & 13 & 0 & $2.6 \times 10^{7}$ \\
30 & $\sim$ & 39 & 0 & $6.6 \times 10^{5}$ \\
45 & $\sim$ & 1 & 0 & $6.6 \times 10^{6}$ \\
60 & $\sim$ & 50 & $0.3 \times 10^{6}$ & $1.3 \times 10^{5}$ \\
75 & $\sim$ & 14 & 0 & $1.5 \times 10^{7}$ \\
\hline
\end{tabular}

Keterangan : = jumlah koloni tidak dapat untuk dihitung

\section{KESIMPULAN}

Sebanyak 158 planlet in vitro $P$. amabilis yang diuji ketahanannya terhadap patogen busuk lunak $D$. dadantii terdistribusi ke dalam 4 kelas ketahanan yaitu sangat rentan (90 planlet), rentan (35 planlet), agak rentan (26 planlet), agak tahan (7 planlet) dan tidak didapatkan sama sekali planlet tahan. Perbedaan ketahanan terhadap penyakit busuk lunak yang disebabkan bakteri $D$. dadantii pada planlet mengindikasikan adanya keragaman genetik planlet walaupun berasal dari hasil penyerbukan sendiri (selfing). Perlakuan bibit dengan asam salisilat (AS) 75 ppm paling baik dalam menginduksi ketahanan bibit $P$. amabilis terhadap penyakit busuk lunak yang disebabkan $D$. dadantii. Perlakuan tersebut juga menghasilkan nilai CFU dan AUPDC yang lebih rendah dan aktivitas peroksidase lebih tinggi dibanding perlakuan lainnya. 


\section{UCAPAN TERIMA KASIH}

Ucapan terima kasih kepada Kemenristek Dikti yang telah mendanai penelitian ini dalam skema Program Tesis Magister (PTM) dengan kontrak Nomor: 1/E1/ KP.PTNBH/2020 dibawah koordinasi Dr. Dewi Sukma, SP. MSi.

\section{DAFTAR PUSTAKA}

Alrich, P., W. Higgins. 2014. Phalaenopsis amabilis (Linnaeus) Blume. Bijdragen tot de Flora van Nederlandsch Indie 24:18-21.

Aziz, S.A., D. Sukma. 2015. Morphological characterization of Phalaenopsis spp. and Hybrids from Indonesia. Acta Hortic. 1078:149-154.

Czajkowski, R., J.M.V.D. Wolf, A. Krolicka, Z. Ozymko, M. Narajczyk, N. Kaczynska, E. Lojkowska. 2015. Salicylic acid can reduce infection symptoms caused by Dickeya solani in tissue culture grown potato (Solanum tuberosum L.) plants. Eur J. Plant Pathol. 141:545-558.

Deenamo, N., A. Kuyogsuy, K. Khompatara, T. Chanwun, K. Ekchaweng, N. Churngchow. 2018. Salicylic acid induces resistance in rubber tree against Phytophthora palmivora. Intl. J. Mol. Sci. 19:1883. Doi:10.3390/ ijms 19071883 .

Dewen, Q., D. Yijie, Z. Yi, L. Shupeng, S. Fachao 2017. Plant immunity inducer development and application. Molecular Plant-Microbe Interactions 30:355-360.

Elina, J. 2016. Respon Ketahanan Anggrek Phalaenopsis terhadap Penyakit Busuk Lunak Akibat Infeksi Dickeya dadantii. Tesis. Sekolah Pascasarjana. Institut Pertanian Bogor. Bogor.

Firgiyanto, R., S.A. Aziz, D. Sukma, Giyanto. 2016. Uji ketahanan anggrek hibrida Phalaenopsis terhadap penyakit busuk lunak yang disebabkan oleh Dickeya dadantii. J. Agron. Indonesia 44:204-210.

Humaira, M., A. Purwito, Sudarsono, D. Sukma. 2020. Multiplikasi tunas in vitro anggrek Phalaenopsis dan analisis keragaman genetik dengan Marka SNAP. J. Agron. Indonesia 47:59-67.

Jendoubi, W., K. Harbaoul, W. Hamada. 2015. Salicylic acidinduced resistance against Fusarium oxysporumf. s.pradicis lycopercisi in hydroponic grown tomato plants. J. New Sciences Agric. Biotech. 21:985-995.
Joko, T., N. Kusumandari, H. Sedyo, 2011. Optimization of PCR methode for the detection of Pectobacterium carotovorum a causal agent of soft rot disease on orchid. J. Perlindungan Tanaman Indonesia 17:5459.

Joko, T., A. Subandi, N. Kusumandari, A. Wibowo, A. Priyatmojo. 2013. Activities of plant cell wall degrading enzymes by bacterial soft rot of orchid. Phytopathol. Plant Protect. 47:1239-1250.

Klessig, D.F., H.W. Choi, D.A. Dempsey. 2018. Systemic acquired resistance and salicylic acid: past, present, and future. Mol. Plant-Microbe Interact. 31:871888.

Leiwakabessy, C., M.S. Sinaga, K.H. Mutaqin, Trikoesoemaningtyas, Giyanto. 2017. Asam salisilat sebagai penginduksi ketahanan tanaman padi terhadap penyakit hawar daun bakteri. J. Fitopatologi Indonesia 13:207-215.

Li, T., Y. Huang, Z.S. Xu, F. Wang, A.S. Xiong. 2019. Salicylic acid-induced differential resistance to the tomato yellow leaf curl virus among resistant and susceptible tomato cultivars. BMC Plant Biol. 19:173.

Meera, T.M., Louis, V., Beena, S. 2016. Diseases of Phalaenopsis symptoms: etiology and management. Intl. J. Agric. Innov. Res. 5:296-300.

Noviantia, R.A., E. Nurcahyani, M.L. Lande. 2017. Uji ketahanan planlet anggrek bulan (Phalaenopsis amabilis (L.) B1.) hasil seleksi dengan asam salisilat terhadap Fusarium oxysporum secara in vitro. J Penelitian Pertanian Terapan 17:132-137.

Prasannath, K. 2017. Plant defense-related enzymes against pathogens: a review. AGRIEAST: J. Agric. Sci. 11:38-48.

Putri, H.A. 2019. Keragaman dan Respon Ketahanan Planlet Phalaenopsis amabilis (L.) Blume Hasil Iradiasi Protocorm tehadap Dickeya dadantii. Tesis. Sekolah Pascasarjana. Institut Pertanian Bogor. Bogor.

Raynalta, E., J. Elina, Sudarsono, D. Sukma. 2018. Clonal fidelity of micro-propagated Phalaenopsis plantlets based on assessment using eighteen Ph-Pto SNAP marker loci. AGRIVITA J. Agric. Sci. 40:390-402.

Rivas, M., S. Vicente, J. Plasencia. 2011. Salicylic acid beyond defence: its role in plant growth and development. J. Exp. Bot. 62:3321-3338. 
Sanjaya, I.P.W., D. Sukma, S.Sudarsono,M.T. Chan. 2020. Effect of genotype, concentration and timing of salicylic acid application to Phalaenopsis against Dickeya dadantii infection. Biodiversitas 21:43174328.

Semiarti, E., I.S. Mercuriana, A. Slamet, B. Sulistyaningsih, I.A.P. Bestari, S. Jang, Y. Machida, C. Machida. 2013. Induction of in vitro flowering of Indonesian wild orchid Phalaenopsis amabilis (L.) Blume. Knowl. Publ. Sci. 2:398-404.

Sudarsono, S., J. Elina, Giyanto, D. Sukma. 2018. Pathogen causing Phalaenopsis soft rot disease-16S rDNA and virulence characterisation. Plant Protect Sci. 54:1-8.

Sukma, D., R. Poerwanto, Sudarsono, N. Khumaida, S. Wiyono, I.M. Artika. 2008. Aktivitas kitinase dan peroksidase dari ekstrak protein daun, akar, kalus dan tunas in vitro Trichosanthes tricuspidata Lour. Bul. Agron. 36:56-63.
Sukma, D., J. Elina, Giyanto, Sudarsono. 2017. Disease resistance breeding of Phalaenopsis spp. for tropical environment and molecular marker development for plant selection. Acta Hortic. 1167:237-243.

Suryowinoto, M. 1990. Pemuliaan Tanaman secara In Vitro. Fakultas Biologi. UGM. Yogyakarta, ID.

Yap, H.S. 2017. Penyakit Cacar Daun Teh (Exobasidium vexans) Tingkat Infeksinya di Perkebunan Gunung Mas (PTPN VIII) dan Bah Butong (PTPN IV). Skripsi. Institut Pertanian Bogor. Bogor.

Yasmin, S., A. Zaka, A. Imran, M.A. Zahid, S. Yousaf, G. Rasul, M. Arif, M.S. Mirza. 2016. Plant growth promotion and suppression of bacterial leaf blight in rice by inoculated bacteria. PloS One 11: e0160688. 